NBER WORKING PAPER SERIES

\title{
THE POLITICAL ECONOMY OF STATE PROVIDED HEALTH INSURANCE \\ IN THE PROGRESSIVE ERA: EVIDENCE FROM CALIFORNIA
}

Dora L. Costa

Working Paper 5328

\author{
NATIONAL BUREAU OF ECONOMIC RESEARCH \\ 1050 Massachusetts Avenue \\ Cambridge, MA 02138 \\ October 1995
}

I have benefitted from the comments of Herbert Emery, Claudia Goldin, Matthew Kahn, Peter Temin, and participants at the 1995 Cliometrics Conference and the 1995 NBER Health Care Summer Institute. I gratefully acknowledge the support of a NIA Aging Fellowship at the National Bureau of Economic Research. This paper is part of NBER's research program in the Development of the American Economy. Any opinions expressed are those of the author and not those of the National Bureau of Economic Research.

() 1995 by Dora L. Costa. All rights reserved. Short sections of text, not to exceed two paragraphs, may be quoted without explicit permission provided that full credit, including () notice, is given to the source. 


\author{
THE POLITICAL ECONOMY OF \\ STATE PROVIDED HEALTH INSURANCE \\ IN THE PROGRESSIVE ERA: \\ EVIDENCE FROM CALIFORNIA
}

\begin{abstract}
I investigate why the United States did not adopt European style health insurance in the 1910s by examining voting determinants on the 1918 referendum on state-provided health insurance in California. I find that although the persuasiveness of interest groups, especially doctors, was an important determinant of the 1918 vote, interest groups alone could not explain the resounding defeat of state-provided health insurance. Voters, I find, were unwilling to pass a costly measure with an unpredictable outcome.
\end{abstract}

Dora L. Costa

Department of Economics, E52

MIT

50 Memorial Drive

Cambridge, MA 02139

and NBER 


\section{Introduction}

Most European nations had adopted social insurance programs by the mid 1910s. These early social insurance programs were the precursors of the modern European welfare state and paved the way for the subsequent expansion of the welfare state. A question that has long puzzled historians is why social insurance programs such as old age, unemployment, and health insurance were not instituted in the United States as well. After all, these social programs were fervently advocated by social reformers, carefully studied by state governments, and debated in state legislatures. The health insurance debates especially have a long political history. The outcome of these debates has determined the structure of current institutions. The United States and Britain had similar institutions in 1910. Had the United States followed the British path and adopted European style health insurance in the 1910 s, the structure of health care may have evolved to more closely resemble that of Europe today.

Nineteenth century social reformers turned to health insurance immediately after the passage of workers' compensation. Health insurance was viewed as actuarilly and administratively the simplest branch of social insurance and the most attractive politically. Sickness affected every member of the family and sickness insurance could be adopted to the mechanism worked out for state industrial accident funds. In 1912, the year that compulsory health insurance was introduced in Britain, the Progressive Party adopted accident, sickness, old age, and unemployment insurance as part of its platform. That same year the American Association for Labor Legislation, an organization of middle class reformers, decided to undertake an active campaign for compulsory health insurance. Commissions were created in several states to study health insurance. Health insurance bills were introduced in several state legislatures. California was the only state in which there was a referendum on state-provided health insurance. A proposed constitutional amendment on the 1918 ballot would have given the legislature the right to establish a system 
of health insurance. Therefore only by examining the California health insurance debate can we begin to understand why state-provided health insurance was never instituted in the United States.

Previous studies of health insurance in California have emphasized the role of doctors, insurance companies, Christian Scientists, and the anti-German hysteria aroused by WWI in the defeat of state-provided health insurance (Viseltear 1969 Starr 1982; Anderson 1951; Ohio Social Insurance Commission 1919). Physicians were co-opted into the British health insurance plan. The failure of American refomers to ally themselves with doctors may have led to the defeat of state-provided health insurance. There may have been less consumer demand for health insurance in the United States. Relatively higher American incomes may have made self-insurance more of an option. Contemporaries were divided over whether there was consumer demand for stateprovided health insurance. This paper provides a quantitative assessment of the persuasiveness of interest groups and of consumer support for the California amendment. Ballot voting is more informative of the preferences of the electorate than legislators' votes which may be influenced by logrolling, constituent interest groups, and ideology and suffer from limited information about the preferences of the electorate (Romer and Rosenthal 1979; Kalt and Zupan 1990; Matsusaka 1992).

The next section of the paper describes the structure of private health insurance. Interest group and consumer support for state provided health insurance will depend upon access to and satisfaction with the current system of private insurance. Proposed state-provided health insurance plans would in part have been based upon existing insurance carriers. The next section thus identifies which groups, based upon their coverage, were likely to support state-provided health insurance. The third section focuses on the arguments made in the nineteenth century for and against health insurance and identifies the major interest groups. The quantitative analysis is presented in the fourth section. The fifth section enhances the quantitative analysis with an examination of 1918 newspaper editorials and advertisements. 


\section{Private Health Insurance in 1918}

One of the factors that a consumer considering the purchase of an insurance policy will take into account is the size of the financial risk being insured. The greater the variance confronting the consumer the higher the demand for insurance. Today the type of coverage most commonly held is for hospital care which has the highest variance of risk. But, in the past the variance of wages lost due to illness was much greater than that due to medical costs incurred because of illness. Early medical technology provided few treatments. The coefficient of variation of lost wages was 310 and that of illness was 107.' Early advocates of health insurance recognized that the "insured workman ... is very much more concerned with the size of the weekly benefit he may expect when he is compelled to 'lay off' because of ill health" than with medical benefits (Rubinow 1916). In fact, the risk that was most commonly insured against was that arising from lost wages. ${ }^{2}$

Wage earners in the 1910 s sought to insure themselves against sickness through fraternal orders, trade union benefits, benevolent societies, commercial hospital associations, commercial insurance companies, and through working for employers who provided medical benefits. ${ }^{3}$ Only those between age 18 to 50 and in good health, as verified by a medical exam, could join an insurance organization. However, once an individual had joined, he could continue to receive benefits even at older ages. Sex and race were often grounds for exclusion except for insurance obtained through commercial insurance companies. Benefits could be collected after an enrollment period of 3 to 6 months. State social insurance commissions in California, Illinois, and Ohio estimated that about one third of the wage earners in those states were insured. However, among prime age

\footnotetext{
${ }^{1}$ Calculated from California Bureau of Labor Statistics (1892) and United States Bureau of Labor Statistics (1917).

${ }^{2} \mathrm{By}$ the 1930s, the coefficient of variation of illness had risen and medical expenditures become the big concern.

${ }^{3}$ For a detailed discussion of policies see Report of the Social Insurance Commission of the State of California and Report of the Health Insurance Commission of the State of Illinois.
} 
wage earners, the fraction was probably higher. Men joined fraternal organizations between age 25-35 and a greater proportion of men aged 35-44 were insured relative to men aged 25-34 or younger (Emery 1993; Whaples and Buffum 1991).

Fraternal orders provided the most important form of insurance. In California an estimated $35 \%$ of all members of fraternal organizations were entitled to sick benefits. Orders paid a cash amount (from $\$ 1$ to $\$ 10$ per week) for a given number of weeks, generally 12 to 13 , to members disabled on account of sickness. ${ }^{4}$ The California Social Insurance Commission reported that only a minority of the lodges provided medical benefits as well as cash and that a few gave doctors' services to the immediate family of members. ${ }^{5}$ When medical benefits were provided, they were generally through a physician employed by the fraternal organization and paid per number of patients covered. Major operations were usually excluded from the service guaranteed as was hospital treatment. Lodge members frequently made donations to cover needs not met by insurance. Except for fraternal orders organized by ethnicity, members were generally the better paid wage earners.

Trade unions were the next largest insurance medium. Approximately $41 \%$ of union members in California and one third in Illinois were protected through their union. Membership was compulsory upon the union men who could meet the requirements. Cash benefits ranged from $\$ 1$ to $\$ 10$ per week and duration of benefits from 6 to 26 weeks, but on the whole the protection provided by unions was less than that offered by fraternals. Medical and hospital care were not provided.

\footnotetext{
${ }^{4}$ The average weekly wage of manufacturing workers was $\$ 14.97$ (Series $802-810$ in U.S. Census Bureau (1975: 170)).

${ }^{5}$ The use of lodge physicians varied widely. For example, in 1914 in North Adams, Massachusetts, 8,000 persons out of a population of 22,000 were in the care of lodge physicians (Rosen 1977). The use of lodge physicians appears to have been more prevalent in Britain where perhaps as many as $60 \%$ of wage earners had access to lodge doctors (Naylor 1986).
} 
Another form of protection was offered by the benevolent society. There were two types of benevolent societies. The first provided only cash benefits and the second owned and maintained a hospital and clinic and had a staff of visiting physicians. Members were entitled to medical, surgical, and hospital care for as long a period as necessary. Commercial hospital associations resembled this latter form of benevolent society. Members of commercial hospital associations were entitled to medical and hospital service for diseases not excluded in the contract. Diseases excluded by most contracts were venereal disease, cancer, tuberculosis, pregnancy, and pre-existing conditions.

Commercial insurance policies were relatively unimportant. In California only about one sixth as many workers were commercial policy holders as were members of fraternal organizations. These policies were written to sometimes cover sickness only, sometimes accident only, and sometimes both sickness and accident. There were two types of commercial insurance policies - commercial and industrial. Industrial policies were targetted towards wage-earning groups, generally the more highly paid wage earners such as mechanics and other skilled labor, and were offered at a monthly premium. Industrial policies insuring against disability arising from one or more of a certain number of diseases or excluding disability due to certain diseases, such as tuberculosis, were also sold. Doubtful risks were given medical examinations. Benefits under most industrial policies were limited to 6 or 8 months and many of the policies restricted the payment of the usual weekly or monthly benefit in case of certain chronic diseases and diseases of long duration to a fraction of the maximum. Commercial policies were sold primarily to business and professional men, farmers, and others of the non-wage earnings classes on an annual premium plan. They provided weekly benefits to compensate for time lost from disability due to sickness or accident, ranging from $\$ 10$ to $\$ 50$ or more and other benefits.

Employers would sometimes provide cash benefits in case of sickness and less often medical, surgical, or hospital care. In Illinois approximately 7.5 to $10 \%$ of the wage earners of 
the state were employed in establishments in which a benefit system was in operation. Payment into establishment funds might be either by employers only, by both employers and employees, or by employees only. Establishment funds were more common among oil, lumber, and mining companies and among railroads than among manufacturing firms, and were expanding. Beginning in 1912, larger employers also provided group life insurance. An employee covered under a group contract who became totally and permanently disabled could collect the income payable in the event of a death as income over a several year period. ${ }^{6}$

The relation between health insurance and worker and household characteristics can be more formally investigated using the 1917-1919 Bureau of Labor Statistics Cost of Living Study which contains information on 12,817 families of wage earners or salaried workers in 99 cities in 42 states. Interviewed households were restricted to those where both spouses and one or more children were present, where salaried workers did not earn more than $\$ 2,000$ a year, where families had resided in the same community for a year prior to the survey, where families did not take in more than three boarders, where families were not classified as either "slum" or charity, and where non-English speaking families had been in the U.S. five or more years. The survey therefore oversamples craft and other high skilled workers relative to factory operatives and laborers and professionals and semi-professionals. Interviewers may also have picked a specific neighborhood in a city. ${ }^{7}$ Because this study focuses on the California debates, black and unknown race households were excluded from the sample, leaving 11,933 households.

The 1917-1919 Cost of Living Survey contained questions on how many people in the household had health insurance and how many people had accident insurance. These questions were answered mainly by those insuring through insurance companies, mutual associations, and

\footnotetext{
${ }^{6}$ For more details on group life insurance see Hoffman (1917).

${ }^{7}$ There are also large numbers of workers from the same industry or firm close together in the sample.
} 
employing associations. Unless the primary purpose of a lodge or union was health insurance or unless the insurance component could be separated from other lodge or union dues, insurance through a fraternal organization or through a union would be counted as expenditures on lodges or unions. Also, because health and accident insurance policies were often sold at one rate of premium, the extent of health insurance alone will be underestimated by the health insurance question. In fact, only ten percent of households reported having health insurance and nineteen percent either health or accident insurance. ${ }^{8}$ If $35 \%$ of all fraternals and $41 \%$ of all unions provided health insurance as the California Social Insurance Commission estimated then about $33 \%$ to $42 \%$ of all households surveyed had health insurance. ${ }^{9}$

A household is assumed to insure if the difference between the risk premium that they would be willing to pay against a risky event and the amount the insurance company charges for risk bearing is greater than zero. The premium that the household will be willing to pay will depend upon income and upon age, because peceptions of risk may change with age, and upon lodge and union membership because these may provide alternative forms of insurance. The amount charged for risk bearing is likely to be related to age, lodge and union membership, and because of differences by industry in the prevalence of employer establishment funds and occupational hazards, industry.

The logarithm of husband's yearly earnings, wife's yearly earnings, children's yearly earnings, income from rent and interest, income from boarders, income from gardens, and all other income is used in the estimation equations. ${ }^{10}$ State social insurance reports regarded income as an important predictor of insurance. Among Illinois husband and wife wage-earner households $38 \%$

\footnotetext{
${ }^{8}$ The numbers are the same for California alone

${ }^{9}$ In the data only ten percent of households reporting lodge expenditures al so reported having health insurance. Similarly, only ten percent reporting union expenditures also reported having health insurance.

${ }^{10}$ Ten cents was added to all incomes to avoid taking logarithms of zero. The use of dummy variable categories rather than the logarithm indicated that the probability of insurance rose with income but at a decreasing rate.
} 
of high income husbands were insured but only $24 \%$ of low income husbands. The number of non-working children is also included in the estimation equations. Age is entered quadratically. ${ }^{11}$ Dummies are used for lodge and union membership. Occupations were divided into 5 classes 1) professionals, semi-professionals, and proprietors, 2) clerical and sales, 3) craft and skilled, 4) service, including personal, and protection, and 5) unskilled laborers. Industries were divided into 14 categories. Region of residence was divided into 8 regions. ${ }^{12}$

Probit equations of the probability of holding health insurance and either health or accident insurance are given in Table 1. The probability of holding insurance rose with age at a decreasing rate. Both lodge and union members were less likely to have insurance, probably because many of them already had insurance through their organizations and did not answer the health insurance question affirmatively. There were large differences by industry in the probability of holding insurance. Workers in extractive industries were the most likely to have insurance. Railroad employees were the next most likely but did not approach the probability of employees in extractive industries. Husband's earnings were the most important component of total earnings in determining the probability of insurance and the amount spent on insurance. However, the impact of earnings was small. The elasticity of insuring with respect to husband's earnings was only 0.10 for health insurance alone and 0.23 for health or accident insurance. When industry dummies were excluded the elasticity for health insurance rose to $0.20{ }^{13}$

The relationship between income and the probability of insurance might be weak because of bias in the dependent variable. Many lodge and union members were not listed as being insured and these workers tended to be relatively well paid. If it is assumed that all lodge and union

\footnotetext{
${ }^{11}$ Tests indicated that this was the best specification for age.

${ }^{12}$ Trying to add state fixed effects to the equation led to multicollinearity problems.

${ }^{13}$ The low elasticity with respect to husband's earnings contrasts with Whaples and Buffum's (1991) findings that among Michigan furniture workers in 1889 a $10 \%$ rise in wages increased the probability of purchasing sickness/accident insurance by about $10 \%$.
} 
Table 1: Probit Estimates of Determinants of Holding Health Insurance and Either Health or Accident Insurance, 1917-1919

\begin{tabular}{|c|c|c|c|c|c|c|c|}
\hline & & \multirow{2}{*}{\multicolumn{3}{|c|}{$\begin{array}{c}\text { health insurance } \\
\text { pseudo } R^{2}=0.08\end{array}$}} & \multirow{2}{*}{\multicolumn{3}{|c|}{$\begin{array}{l}\text { health or accident } \\
\text { pseudo } R^{2}=0.10\end{array}$}} \\
\hline 11993 obs & & & & & & & \\
\hline variables & mean & coef & std err & $\frac{\partial P}{\partial x}$ & coef & std err & $\frac{\partial P}{\partial x}$ \\
\hline $\begin{array}{l}\text { intercept } \\
\text { log of yearly }\end{array}$ & & $-3.6342^{1}$ & 0.5594 & & $-3.7208^{\ddagger}$ & 0.4347 & \\
\hline husband's earnings & 7.17 & $0.1314^{*}$ & 0.0685 & 0.0210 & $0.3011^{\ddagger}$ & 0.0525 & 0.0589 \\
\hline wife's earnings & -1.72 & 0.0024 & 0.0012 & 0.0004 & 0.0084 & 0.0074 & 0.0016 \\
\hline children's earnings & 12.0 & $0.0162^{\dagger}$ & 0.0074 & 0.0026 & 0.0069 & 0.0061 & 0.0014 \\
\hline rent and interest & -1.71 & $0.0213^{\dagger}$ & 0.0089 & 0.0034 & $0.0189^{\ddagger}$ & 0.0076 & 0.0037 \\
\hline income from boarders & -1.97 & 0.0050 & 0.0113 & 0.0008 & 0.0044 & 0.0096 & 0.0008 \\
\hline income from gardens & -0.13 & 0.0003 & 0.0068 & 0.0000 & $0.0101^{*}$ & 0.0057 & 0.0020 \\
\hline other income & -1.62 & $0.1284^{\ddagger}$ & 0.0077 & 0.0205 & $0.1146^{\ddagger}$ & 0.0071 & 0.0224 \\
\hline number non-working children & 2.27 & -0.0038 & 0.0178 & -0.0006 & -0.0233 & 0.0153 & -0.0046 \\
\hline age & 36.93 & $0.0413^{t}$ & 0.0142 & 0.0066 & $0.0221^{\dagger}$ & 0.0112 & 0.0043 \\
\hline $\begin{array}{l}\text { age squared } \\
\text { dummy }=1 \text { if member }\end{array}$ & & $-0.0004^{\dagger}$ & 0.0002 & -0.0000 & $-0.0002^{*}$ & 0.0001 & -0.0000 \\
\hline lodge & 0.29 & -0.0397 & 0.0368 & -0.0064 & 0.0177 & 0.0308 & 0.0035 \\
\hline union & 0.31 & -0.0524 & 0.0376 & -0.0084 & -0.0467 & 0.0318 & -0.0091 \\
\hline $\begin{array}{l}\text { dummy }=1 \text { if occupation } \\
\text { professional or semi-professional }\end{array}$ & 0.07 & & & & & & \\
\hline clerical or sales & 0.15 & 0.0680 & 0.0816 & 0.0109 & -0.0037 & 0.0651 & -0.0007 \\
\hline skilled & 0.38 & 0.0565 & 0.0736 & 0.0090 & -0.0281 & 0.0592 & -0.0055 \\
\hline service & 0.06 & 0.0357 & 0.0989 & 0.0057 & -0.0553 & 0.0809 & -0.0108 \\
\hline laborer & 0.34 & 0.0875 & 0.0754 & 0.0140 & -0.0317 & 0.0608 & -0.0062 \\
\hline dummy $=1$ if industry & & & & & & & \\
\hline personal, repair, service, sales & 0.12 & & & & & & \\
\hline government & 0.07 & $0.3903^{\ddagger}$ & 0.0820 & 0.0625 & $0.3555^{\ddagger}$ & 0.0665 & 0.0695 \\
\hline construction & 0.05 & -0.0438 & 0.1130 & -0.0070 & $-0.1898^{\dagger}$ & 0.0920 & -0.0371 \\
\hline steel or steel products, chemical, rubber & 0.16 & $0.3623^{\ddagger}$ & 0.0731 & 0.0581 & $0.2727^{\ddagger}$ & 0.0584 & 0.0533 \\
\hline railroad & 0.11 & $0.4720^{\ddagger}$ & 0.0762 & 0.0755 & $0.5218^{\downarrow}$ & 0.0604 & 0.1020 \\
\hline other transport and transport production & 0.13 & $0.2712^{\ddagger}$ & 0.0761 & 0.0434 & $0.1878^{\ddagger}$ & 0.0607 & 0.0367 \\
\hline lumber & 0.04 & $0.2733^{\ddagger}$ & 0.1043 & 0.0437 & $0.3238^{\ddagger}$ & 0.0841 & 0.0633 \\
\hline utilities & 0.02 & 0.2134 & 0.1404 & 0.0341 & 0.1608 & 0.1136 & 0.0314 \\
\hline food manufacturing & 0.06 & $0.2079^{\ddagger}$ & 0.0933 & 0.0333 & 0.0913 & 0.0753 & 0.0179 \\
\hline printing & 0.02 & $0.2488^{*}$ & 0.1363 & 0.0398 & 0.1060 & 0.1139 & 0.0208 \\
\hline textiles & 0.05 & $0.3800^{\ddagger}$ & 0.0946 & 0.0608 & 0.2129 & 0.0800 & 0.0416 \\
\hline extractive industries & 0.04 & $0.8065^{\ddagger}$ & 0.0920 & 0.1290 & $0.8485^{\ddagger}$ & 0.0789 & 0.1659 \\
\hline communications and financial & 0.02 & 0.0090 & 0.1376 & 0.0014 & -0.0604 & 0.1063 & -0.0118 \\
\hline miscellaneous manufacturing or unknown & 0.10 & $0.2124^{\ddagger}$ & 0.0803 & 0.0340 & 0.1040 & 0.0649 & 0.0203 \\
\hline
\end{tabular}

Note. Regional dummies were included in both specifications. The symbols $*, \dagger$, and $\ddagger$ indicate that the coefficient is significantly different from 0 at at least the 10,5 , and 1 percent level, respectively. $\frac{\partial P}{\partial x}=\beta \frac{1}{n} \sum \phi\left(x^{\prime} \beta\right)$, where $\phi$ is the standard normal density, and is in probability units. 
members had health insurance then the elasticity of insuring with respect to husband's earnings is still only 0.18 .

A more likely explanation for the weak relationship between income and the probability of insurance is that higher income households could depend upon savings and lower income households upon either increased labor participation of other family members, reductions in expenditures, or charity. Charity was provided by county governments and by private organizations. Free medical, dental, and nursing care could be obtained from county hospitals, city governments, neighborhood health centers, or free private clinics. California made its counties responsible for the health care of poor persons in 1855 (Shonick 1995). Friends and neighbors were other important sources of non-market insurance (Whaples and Buffum 1991).

The opponents of state-provided health insurance argued that the reason so few wageearners were insured was because there was simply not that much need for health insurance. Sickness was infrequent and easily covered by savings. The California Social Insurance Commission estimated that wage earners lost at most 6 days per year or about one work week due to illness. Those who experienced some sickness lost on average 5 weeks. In the 1917-1919 Cost of Living Study, the average household had yearly savings worth 2.8 weeks' of the husband's weekly wage. The average cost of health insurance to those households that did have it was equal to one-half of the husband's weekly earnings. When households were divided into quartiles according to husband's weekly earnings those in the lowest quartile had yearly savings totalling 1.2 weeks of the husband's weekly earnings and those in the highest quartile yearly savings totalling 4.4 weeks. Insurance through a fraternal was less expensive. The California Social Insurance Commission estimated that many fraternals charged $\$ 9$ per year, or $35 \%$ of the weekly earnings of husbands in the 1917-1919 Cost of Living Survey, for benefits of $\$ 5-\$ 10$ per week for up to 13 weeks. Thus, although the benefits were less generous than those of commercial insurance companies, premiums were less expensive and benefits more than covered expected 
sickness days.

Proponents of state-provided health insurance acknowledged that fraternals could provide insurance coverage at a fraction of commercial insurers' costs because local lodges had more complete information about their members than insurance companies ever could, but questioned whether relatively small lodges could be safe sources of insurance. They admitted that commercial insurance companies were financially stable, but argued that the premiums of commercial insurance companies were high because of the moral hazard problem. The failure of individuals to insure could therefore be attributed to the high costs of insurance. Recent work, however, suggests that fraternal lodges had almost no probability of being bankrupted by high claims because surplus revenues were invested in assets which generated income that subsidized lodge operations and benefit payments (Emery 1993). Access to health insurance thus appears not to have been determined primarily by income.

The relatively weak relationship between health insurance and income is mirrored by the relatively weak relationship between medical expenditures and income. The share of medical expenditures is constant across income categories (see Table 2). How the medical care budget was spent was also relatively similar across income categories. The greatest expenditures, in order of magnitude, were on doctors, drugs, and dentists. Although the wealthier spent relatively more on dentists and eye glasses and relatively less on doctors and drugs, income does not appear to determine access to medical care. ${ }^{14}$

\footnotetext{
${ }^{14}$ There was no evidence that those living in smaller cities had less access to medical care. In fact, expenditures on medical care were somewhat greater in smaller cities.
} 
Table 2: Budget Share Devoted to Medical Care and Share of Medical Care Budget Devoted to Various Medical Expenditures by Annual Income

\begin{tabular}{|c|c|c|c|c|c|c|}
\hline & \multirow{2}{*}{$\begin{array}{c}\text { all } \\
\text { house- } \\
\text { holds }\end{array}$} & \multicolumn{5}{|c|}{ household income } \\
\hline & & $<\$ 1176$ & $\$ 1176-1350$ & $\$ 1350-1550$ & $\$ 1550-1827$ & $\geq \$ 1827$ \\
\hline direct medical expenditures & 4.1 & 4.0 & 4.1 & 4.2 & 4.3 & 4.0 \\
\hline medical, health and accident & & & & & & \\
\hline insurance expenditures & 4.2 & 4.2 & 4.3 & 4.4 & 4.6 & 4.3 \\
\hline as $\%$ direct medical expenditures & & & & & & \\
\hline doctors & 47.8 & 49.9 & 49.8 & 47.7 & 46.7 & 45.1 \\
\hline drugs & 25.4 & 29.4 & 25.7 & 24.5 & 24.2 & 23.4 \\
\hline dentists & 15.1 & 10.7 & 13.7 & 15.1 & 16.9 & 19.2 \\
\hline nurses & 3.4 & 3.3 & 3.5 & 3.7 & 3.7 & 2.9 \\
\hline eye glasses & 4.3 & 3.4 & 3.6 & 3.7 & 3.7 & 5.6 \\
\hline hospitals & 0.1 & 0.1 & 0.1 & 0.1 & 0.1 & 0.1 \\
\hline other medical products & 0.3 & 0.3 & 0.4 & 0.3 & 0.3 & 0.2 \\
\hline
\end{tabular}

Note. Calculated from 1917-1919 Cost of Living Survey restricted to white households.

\section{Debating State-Provided Health Insurance}

The health insurance plan that received the most publicity was the American Association for Labor Legislation's (AALL) "Standard Bill" published in 1915. The plan was similar to that prevailing in Germany. Health insurance was to be compulsory for every employed person earning $\$ 1,200$ per year or less, with special provisions covering casual and home workers and those who wished to insure voluntarily under the act. ${ }^{15}$ Contributions for benefits were to come from the state, employees, and from employers. On the fourth day of illness, a cash benefit equal to two-thirds of the weekly wage was to be paid for a period not exceeding 26 weeks in a year. All necessary medical, surgical, and nursing attendance and treatment were to be furnished from the first day of illness for a period not to exceed 26 weeks in any one year. ${ }^{16}$ Provisions were

\footnotetext{
${ }^{15}$ The sum of $\$ 1,200$ was above the average earnings of all wage earners.

${ }^{16}$ Hospital care was simply not a concern in the 1910s. As seen in Table 2 only a small share of all expenditures on medical care went to hospital care. County and private charity expenses were relatively small as well. Only $13 \%$
} 
also made for maternity and funeral benefits. Medical service was to be provided by insurance carriers through either 1) a state panel of physicians from which patients could choose their doctor; 2) salaried physicians employed by the carrier among whom the insured had reasonable free choice; and 3) district medical officers, engaged for treatment of insured persons in prescribed areas. These insurance carriers might be either fraternals, trade funds, establishment funds, trade unions, or state local funds. However, the $40 \%$ employer contribution went to the state fund alone, thus effectively excluding all other insurance carriers. Commercial insurance companies were explicitly excluded. The state local funds were to be centrally administered by a State Social Health Insurance Commission within a multi-tiered bureacratic organization. Renumeration of physicians was to be set at a rate approved by the Commission.

Although the California Social Insurance Committe did not explicitly draft a health insurance bill, in their final report the Committe proposed a health insurance scheme slightly different from the AALL's. Insurance would be compulsory for all workmen below a specified income level, perhaps $\$ 1,200$ or $\$ 1,500$. Under their proposed plan a state health insurance fund would be established. This fund would be the sole carrier of medical benefits and one but not the sole carrier of cash benefits. Workmen would pay the entire cost of the cash benefit and would choose their own insurance carriers. ${ }^{17}$ Thus, unlike the AALL plan, unions, fraternal societies, and other voluntary organizations would not be excluded. ${ }^{18}$ Employers and the state would contribute to the medical benefit. Physicians would be organized in districts and supervised by medical inspectors. Their fees would be set. The insured would be able to choose from any

of all expenditures on medical care and health insurance in consumer income accounts went to hospital expenditures (calculated from Dewhurst and Associates (1955).

${ }^{17}$ The Commission believed that by having workmeen pay the entire cost of the cash benefit, malingering could be avoided.

${ }^{18}$ In its inclusion of fraternal societies, the California Social Insurance Commission's plan more closely resembled the British rather than the German plan. 
physician registered with the district. There would be limits on the duration of both medical and cash benefits. The Commission favored a somewhat different organizational form than that proposed by the AALL. Because the Social Insurance Commission believed that there were constitutional obstacles in the path of legislative action, they recommended that a constitutional amendment enabling the legislature to establish a system of health insurance be submitted to the people (California Social Insurance Commission 1917). ${ }^{19}$

The arguments for and against health insurance were publicized on both the national and the state level. ${ }^{20}$ Proponents of health insurance argued that the state could provide larger and more extensive benefits than private insurance carriers because by insuring a larger group of people aggregate risk would be lower and because many selling and administrative costs would be eliminated. Furthermore, the results of sickness were so disastrous that sickness was a community concern. Proponents of health insurance stressed that ill health often led to families becoming charity cases. Another argument made by the proponents of health insurance was that only by compulsion was it possible to distribute throughout industry the burden of sickness. Sickness was a result of the action or inaction of the state (public health measures), of employers (working conditions), and of employees (personal health habits). Because the costs of insurance were spread among all three groups, all three groups would take actions to improve health and to lower premiums. ${ }^{21}$ The average health of the nation would thus improve.

The opponents of national health insurance argued that state provided health insurance would not improve health. Public health measures were needed. They pointed out that in the German case there was no integration of health insurance and public health agencies and that

\footnotetext{
${ }^{19}$ The proposal of an enabling amendment should not be regarded as unusual. In California workers' compensation was initially struck down by the courts and passed only by amending the California constitution.

${ }^{20}$ See Ohio Health and Old Age Insurance Commission (1919), Illinois Social Insurance Commission (1919), California Social Insurance Commission (1917), Hoffman (1917), Warren and Sydenstricker (1916), among others.

${ }^{21}$ Oddly enough, the issue of free riding never came up.
} 
the health of the United States compared favorably with that of Germany. They also argued that poverty would not be avoided by compulsory health insurance. The unemployed were the ones likely to be left out of the system. The poor would be better helped by a state medical service, better poor relief, and the establishment and adequate maintenance of community hospitals. One of the big concerns of opponents was cost. The California Social Insurance Commission estimated that costs would range from $\$ 14,651,000$ to $\$ 28,780,000$ per annum. ${ }^{22}$ There was fear that costs would be raised by malingering on the part of individuals and by graft and mismanagement and that only "politicians and job chasers" would benefit. ${ }^{23}$ In addition to the total costs, there was concern with the distribution of costs. Why should all of society have to pay for sickness caused by personal habits or by industry specific working conditions? Shouldn't industry specific illness be covered by workers' compensation instead?

The major interest groups lobbying for or against state provided health insurance were middle class Progressive organizations such as the AALL, unions, employers, doctors, druggists, and insurance companies and fraternals. ${ }^{24}$ Unions were divided. The American Federation of Labor, led by Samuel Gompers, was opposed. In California the San Francisco Labor Council was opposed, while the California Federation of Labor and the California Building Trades Council were in favor (Skocpol 1992: 238, 244). Opposition to the measure arose from the belief that the measure might undermine union activity, prove to be a palliative and a substitute for better

\footnotetext{
${ }^{22}$ There was a high variance in estimates of the cost of insurance. The AALL estimated that $4 \%$ of payroll would be needed to cover lost wages, medical aid, and maternity and funeral benefits. The Illinois Social Insurance Commission estimated that $7.5 \%$ of payroll would be needed to cover lost wages and medical care alone (cited in Starr 1982: 254).

${ }^{23}$ This was argued in one of the pamphlets sponsored by the California Research Society of Social Economics. In May of 1917 there was a full page advertisement in the annual edition of the San Francisco Chronicle paid for by the Insurance Federation of California in which it was stated that health insurance would become political graft so gigantic that the political party in power at the time health insurance was adopted could perpetuate itself (Viseltear 1969).
}

${ }^{24}$ See Ohio Health and Old Age Insurance Commission 1919 and Starr 1982. 
wages, hours, and conditions of labor, create class divisions, and induce further state regulation of the worker's purely personal affairs.

Employers argued that the initial expense of the insurance could not be absorbed in the costs of production and shifted to consumers. They feared that employers in states which adopted it would be at a disadvantage in competition with those of other states. The National Association of Manufactures took no stand on health insurance, but the National Industrial Conference Board was represented in various state legistlative hearings and at various public forums in California.

Although the American Medical Association (AMA) had established a social insurance commission in 1915 and although many of the most prominent supporters of the AALL's plan were physicians, the AMA took no stand on health insurance, except to insist that any proposed legislation should provide for freedom of choice of physician by the patient; payment of the physician in proportion to the amount of work done; the separation of the function of medical official supervision from the function of daily care of the sick; and the adequate representation of the medical profession on the appropriate administrative bodies. Some doctors argued that health insurance would benefit the medical profession by increasing the size of the average physicians' practice. Table 2 suggests that any increases would have been small. Nonetheless, some of the leaders of the California state medical society favored compulsory health insurance. The state medical society took no stand, but a group of doctors formed an independent association to oppose the constitutional amendment. Doctors' opposition sprang in part from the fact that no specific bill had been drafted. Before the California popular vote doctors sent open letters and pamphlets to their patients and other physicians warning them against health insurance (Viseltear 1969).

Other medical personnel, such as nurses, dentists, druggists, occulists, and hospitals demanded that they too be represented in any state health insurance bureaucracy, fearing that 
doctors might benefit at their expense. ${ }^{25}$ Insurance companies and fraternals also feared being shut out from health insurance and under the AALL's plan they would have been. They published pamplets, paid for newspaper advertising, and when the proposed constitutional amendment was placed on the California ballot, sent personal communications to their members, asking that they vote against the amendment. Contemporaries estimated that they reached over 200,000 voters (Ohio Health and Old Age Insurance Commission 1919).

Another group whom contemporaries believed to be a potent force in the battle over health insurance were Christian Scientists. Christian Scientists wrote editorials and organized "publicity committees" in San Francisco and Los Angeles to assist them in their campaign against health insurance.

\section{Voting on State-Provided Health Insurance}

Both the State Senate and Assembly passed the proposed constitutional amendment in 1917 . In the Senate the vote was 32 to 3 with the only nay votes among senators from Los Angeles. ${ }^{26}$ In the Assembly the vote was 55 to 11 . The only predictors (positive) of a nay vote in the Assembly were whether a county was either a big lumber or mineral producer, but even in these counties there was little opposition. After the constitutional amendment was passed by the Legislature, the campaign against state-provided health insurance intensified. On election day, the health insurance amendment was defeated by 358,324 votes to 133,858 .

Although 714,525 voters showed up at the polls on election day, only 492,182 voted on the health insurance amendment. In contrast, 688,670 voted for a gubernatorial candidate

\footnotetext{
${ }^{25}$ Druggist could point to the "floating six-pence" of the British health insurance act, whereby the physicians" fund benefited from a reduction in the amount of drugs prescribed.

${ }^{26}$ By 1916 southern California was the stronghold of anti-Progressive sentiment. Progressive strength was strongest among San Francisco workers and the Catholic foreign-stock counties of the Bay Area (Rogin and Shover 1970).
} 
and 582,131 voted on the prohibition amendment. Because so many voters abstained on the health insurance amendment, I use Deacon and Shapiro's (1975) voting model. In their model, an individual is assumed to vote for health insurance if utility under the health insurance outcome is perceptibly greater than utility under the no health insurance outcome. If the difference in utility under the two alternative outcomes is not perceptible, the individual will be indifferent. Suppose that the difference between utilities resulting from the passage and the defeat of health insurance is $\Delta u_{i}$ for individual $i$. An individual will vote yes if $\Delta u_{i}>\delta_{i}$, no if $\Delta u_{i}<-\delta_{i}$, and abstain otherwise. The term $\delta_{i}$ can be interpreted as a measure of the precision with which and individual is able to distinguish between the two alternatives. I assume that $\delta_{i}=x_{i} \gamma^{\prime}$, where $x_{i}$ is a vector containing variables that reflect experience, predisposition, and contextual knowledge. I assume that $\Delta u_{i}$ is distributed logistically with mean $\mu_{i}$, that is $P\left(\Delta u_{i}<x_{i}\right)=\Lambda\left(x_{i}-\mu_{i}\right)$, where $\Lambda$ is the logistic distribution. I assume that $\mu_{i}=z_{i} \alpha^{\prime}+x_{i} \beta^{\prime}$, where $z_{i}$ is a vector containing variables of socioeconomic characteristics and voter attributes that are relevant to the health insurance referendum, such as the proportion of voters in an affected group.

The model is estimated with county level data using Berkson's minimum chi-squared technique by jointly estimating

$$
\begin{aligned}
\ell(Y) & =z_{i} \alpha^{\prime}+x_{i}\left(\beta^{\prime}-\gamma^{\prime}\right) \\
\ell(Y)+\ell(N) & =-2 x_{i} \gamma^{\prime}
\end{aligned}
$$

where $\ell(Y)=\log \left(\frac{P(Y)}{1-P(Y)}\right), \ell(N)=\log \left(\frac{P(N)}{(1-P(N)}\right), P(Y)$ is the probability of voting yes, and $P(N)$ is the probability of abstaining (see Deacon and Shapiro 1975; Shapiro 1973). The estimated coefficients of the first equation give the overall effect of the independent variables upon the probability of voting in favor of the proposition, while the estimated coefficients of the 
second equation give the overall effects of voting on the iniative at all. The values of $\alpha$ and $\beta$ can be derived from the estimated equations and give the effects of the independent variables upon expected changes in utility. The estimates of $\gamma$ give the impact of the independent variables upon the perception threshhold.

Voter attributes that are directly relevant to the health insurance referendum are, per voting age individual, the value of crops, of manufactures, and of mineral wealth, and the taxable wealth of railroads; whether a county was a lumber producer; city size; and the number of hospital beds per capita. Demand for health insurance should vary by type of industry. As previously noted, workers in the railroad, lumber, and mining industries were already more likely to have insurance than workers in other industries. If they were satisfied with their existing benefits they might not wish to try a new system. Farm communities in which self-employment was high probably saw the measure as benefiting largely manufacturing. Workers in manufacturing might favor the health insurance amendment because they would receive the benefit but part of the cost would be paid from general taxation. Areas without medical facilities might regard access rather than payment as one of the true problems.

Varibles that reflect experience, predisposition and contextual knowledge are the logarithm of taxable wealth per voting age individual; for the voting age population, the percentage of foreign-born, illiterates, union members, and doctors; the fraction of members of religious denominations who were Christian Scientists; and the percentage of the vote cast for Wilson and Benson in the 1916 presidential election. Although numerically small, doctors, Christian Scientists, and union members are alleged to have been effective advocates for or against health insurance. Supporters of Benson (the Socialist candidate) and of Wilson (the Democratic candidate) in the 1916 presidential election should be more likely to favor insurance compared to supporters for Hughes (the Republican candidate). In California, workers and Progressives voted for Wilson (Rogin and Shover 1970). 
Two specifications are given (see Tables 3 and 4). The first specification contains the past voting variables. The second does not. The estimated coefficients in the first column of Table 3 thus indicate the residual effects of socio-economic and demographic characteristics on the probability of voting for the amendment and the residual effects of political affiliation controlling for socio-economic and demographic characteristics on the probability of voting for the amendment. But, if political affiliation is a function of the given socio-economic and demographic characteristics, then the full impact of the socio-economic and demographic characteristics is indicated by the second specification. However, if any socio-economic and demographic variables that determine party affiliation have been incorrectly excluded from the specification, then the first equation is the correct specification. ${ }^{27}$

The regression results indicate that industry, which predicted the probability of having health insurance, was negatively, but insignificantly, related to the probability of voting for the constitutional amendment. City size was positively related to the probability of voting for the amendment, and significantly so when past voting variables were omitted from the regression. When the percentage of voters over age 45 and of women of voting age was added to the regressions, the coefficients were positive but highly insignificant, suggesting that the unavailability of health insurance at older ages or to women did not lead to age or sex differences in voting patterns. Wealth, another predictor of the probability of having health insurance was in Table 3 a significant, negative predictor of the probability of voting for health insurance, an insignificant, negative predictor of abstention and of the mean difference between utilities resulting from the act's passage and its defeat, $\mu$. When past voting is omitted from the regression

\footnotetext{
${ }^{27}$ The problem then becomes one of interpreting pastvoting behavior. Peltzman (1984) finds that with increasingly better economic variables the impact of party affiliation declines and suggests that party affiliation reflects not ideology but economic self-interest. Poole and Rosenthal (1993) find that once an ideology measure has been used, the marginal explanatory power of the economic self-interest variables is minimal and hence argue that voting is best described by ideology.
} 
Table 3: Determinants of Vote on 1918 Health Insurance Referendum

\begin{tabular}{|c|c|c|c|c|c|c|c|}
\hline 58 obs, adjusted $R^{2}=0.95$ & & \multicolumn{2}{|c|}{$\ell(Y)$} & \multicolumn{2}{|c|}{$\ell(Y)+\ell(N)$} & $\mu$ & $\delta$ \\
\hline county level variables & mean & $\alpha,(\beta-\gamma)$ & $\frac{\partial L}{\partial x}$ & $-2 \gamma$ & $\frac{\partial L}{\partial x}$ & $\alpha, \beta$ & $\gamma$ \\
\hline intercept & & $\begin{array}{l}-0.4850 \\
(1.0621)\end{array}$ & & $\begin{array}{l}-0.3894 \\
(0.9440)\end{array}$ & & $\begin{array}{l}-0.4850 \\
(1.0621)\end{array}$ & $\begin{array}{c}0.1947 \\
(0.4720)\end{array}$ \\
\hline value per voting age individual & & & & & & & . \\
\hline logarithm of taxable wealth & 8.08 & $\begin{array}{l}-0.2510^{\dagger} \\
(0.1276)\end{array}$ & -0.0101 & $\begin{array}{l}-0.1588 \\
(0.1122)\end{array}$ & -0.0064 & $\begin{array}{l}-0.1716 \\
(0.2167)\end{array}$ & $\begin{array}{c}0.0794 \\
(0.0561)\end{array}$ \\
\hline$\%$ voting age pop doctors & 0.21 & $\begin{array}{l}-1.8259 \\
(0.6676)\end{array}$ & -0.0731 & $\begin{array}{l}-0.4400 \\
(0.5464)\end{array}$ & -0.0176 & $\begin{array}{l}-1.6059 \\
(1.0822)\end{array}$ & $\begin{array}{c}0.2200 \\
(0.2730)\end{array}$ \\
\hline$\%$ religious members Christian & & & & & & & \\
\hline Scientists $\times 100$ & 14.34 & $\begin{array}{c}0.0010 \\
(0.0051)\end{array}$ & 0.0000 & $\begin{array}{c}0.0003 \\
(0.0038)\end{array}$ & 0.0000 & $\begin{array}{c}0.0008 \\
(0.0079)\end{array}$ & $\begin{array}{l}-0.0002 \\
(0.0019)\end{array}$ \\
\hline$\%$ voting age pop union members & 3.40 & $\begin{array}{c}0.0154 \\
(0.0120)\end{array}$ & 0.0006 & $\begin{array}{c}0.0113 \\
(0.0118)\end{array}$ & 0.0005 & $\begin{array}{c}0.0098 \\
(0.0219)\end{array}$ & $\begin{array}{l}-0.0056 \\
(0.0059)\end{array}$ \\
\hline$\%$ voting age pop illiterate & 6.12 & $\begin{array}{l}-0.0284 \\
(0.0207)\end{array}$ & -0.0011 & $\begin{array}{l}-0.0464^{\ddagger} \\
(0.0180)\end{array}$ & -0.0019 & $\begin{array}{l}-0.0053 \\
(0.0350)\end{array}$ & $\begin{array}{r}0.0232^{\dagger} \\
(0.0090)\end{array}$ \\
\hline$\%$ voting age pop foreign-born & 24.12 & $\begin{array}{c}0.0100 \\
(0.0063)\end{array}$ & 0.0004 & $\begin{array}{r}0.0269^{\ddagger} \\
(0.0054)\end{array}$ & 0.0011 & $\begin{array}{l}-0.0035 \\
(0.0105)\end{array}$ & $\begin{array}{l}-0.0315^{\ddagger} \\
(0.0027)\end{array}$ \\
\hline$\%$ votes cast for Wilson in 1916 & 49.73 & $\begin{array}{r}0.0256^{\ddagger} \\
(0.0097)\end{array}$ & 0.0010 & $\begin{array}{c}-.0010 \\
(0.0079)\end{array}$ & -0.0000 & $\begin{array}{r}0.0261^{*} \\
(0.0158)\end{array}$ & $\begin{array}{c}0.0005 \\
(0.0040)\end{array}$ \\
\hline$\%$ votes cast for Benson in 1916 & 5.22 & $\begin{array}{c}0.0003 \\
(0.0249)\end{array}$ & 0.0000 & $\begin{array}{l}-0.0535^{\dagger} \\
(0.0229)\end{array}$ & -0.0021 & $\begin{array}{c}0.0272 \\
(0.0440)\end{array}$ & $\begin{array}{r}0.0268^{\dagger} \\
(0.0115)\end{array}$ \\
\hline $\begin{array}{l}\text { value per voting age individual } \\
\text { crops }\end{array}$ & 484.54 & $\begin{array}{l}-0.0001 \\
(0.0001)\end{array}$ & -0.0000 & . & & $\begin{array}{c}-0.0001 \\
(0.0001)\end{array}$ & . \\
\hline manufacturing products & 0.65 & $\begin{array}{c}0.0187 \\
(0.0246)\end{array}$ & 0.0008 & . & & $\begin{array}{c}0.0187 \\
(0.0246)\end{array}$ & . \\
\hline mineral products & 45.32 & $\begin{array}{l}-0.0003 \\
(0.0004)\end{array}$ & -0.0000 & . & & $\begin{array}{l}-0.0003 \\
(0.0004)\end{array}$ & . \\
\hline railroad assessments & 215.81 & $\begin{array}{l}-0.0001 \\
(0.0001)\end{array}$ & -0.0000 & . & & $\begin{array}{l}-0.00001 \\
(0.0001)\end{array}$ & . \\
\hline dummy $=1$ if county lumber producer & 0.17 & $\begin{array}{l}-0.0951 \\
(0.0822)\end{array}$ & -0.0038 & . & & $\begin{array}{l}-0.0951 \\
(0.0822)\end{array}$ & . \\
\hline dummy $=1$ if city of $25,000+$ & 0.12 & $\begin{array}{c}0.0861 \\
(0.0743)\end{array}$ & 0.0034 & . & & $\begin{array}{c}0.0861 \\
(0.0743)\end{array}$ & . \\
\hline no of hospital beds per capita & 0.01 & $\begin{array}{l}-0.1766 \\
(1.7121)\end{array}$ & -0.0071 & . & & $\begin{array}{l}-0.1766 \\
(1.7121)\end{array}$ & . \\
\hline
\end{tabular}

Note. Standard errors are in parentheses. The symbols $*, \dagger$ and $\ddagger$ indicate that the coefficient is significantly different from 0 at least the 10,5 , and 1 percent level, respectively. $\frac{\partial L}{\partial x}=\beta \frac{1}{n} \sum L(1-L)$, where $\beta$ is the vector of estimated coefficients, $L$ is the logistic distribution, and $\frac{\partial L}{\partial x}$ is in probability units.

Sources. Voting data is from California Registrar of Voters (1918) and Clubb et al. Assessed values are from California State Board of Equalization (1918). Mineral production values are from California Blue Book, 1911. Values are for 1910. Information on lumber production within a county is from California State Tax Commission (1917). Union membership was estimated from California Bureau of Labor Statistics (1918). Religious membership was extrapolated from Census of Religious Bodies, 1906 and 1926. The number of hospital beds and of doctors by county was compiled from American Medical Association (1918). All other information is from ICPSR's Historical Demographic, Economic, and Social Data. 
Table 4: Determinants of Vote on 1918 Health Insurance Referendum, Excluding Political Affiliation

\begin{tabular}{|c|c|c|c|c|c|c|c|}
\hline $58 \mathrm{obs}$, adjusted $R^{2}=0.94$ & & \multicolumn{2}{|c|}{$\ell(Y)$} & \multicolumn{2}{|c|}{$\ell(Y)+\ell(N)$} & $\mu$ & $\delta$ \\
\hline county level variables & mean & $\alpha,(\beta-\gamma)$ & $\frac{\partial L}{\partial x}$ & $-2 \gamma$ & $\frac{\partial L}{\partial x}$ & $\alpha, \beta$ & $\gamma$ \\
\hline intercept & & $\begin{array}{c}0.3866 \\
(1.0387)\end{array}$ & & $\begin{array}{l}-0.9615 \\
(0.9446)\end{array}$ & & $\begin{array}{c}0.3866 \\
(1.0387)\end{array}$ & $\begin{array}{c}0.4808 \\
(0.4723)\end{array}$ \\
\hline $\begin{array}{l}\text { value per voting age individual } \\
\text { logarithm of taxable wealth }\end{array}$ & 8.08 & $\begin{array}{l}-0.1340 \\
(0.1320)\end{array}$ & -0.0056 & $\begin{array}{l}-0.1328 \\
(0.1152)\end{array}$ & -0.0055 & $\begin{array}{l}-0.0676 \\
0.2233\end{array}$ & $\begin{array}{c}0.0664 \\
(0.0576)\end{array}$ \\
\hline$\%$ voting age pop doctors & 0.21 & $\begin{array}{l}-2.1387^{\ddagger} \\
(0.6821)\end{array}$ & -0.0891 & $\begin{array}{c}0.0030 \\
(0.5468)\end{array}$ & 0.0001 & $\begin{array}{l}-2.1402^{\dagger} \\
(1.0932)\end{array}$ & $\begin{array}{l}-0.0015 \\
(0.2734)\end{array}$ \\
\hline$\%$ religious members Christian & & & & & & & \\
\hline Scientists $\times 100$ & 14.34 & $\begin{array}{l}-0.0106^{\ddagger} \\
(0.0030)\end{array}$ & -0.0004 & $\begin{array}{c}0.0026 \\
(0.0026)\end{array}$ & 0.0001 & $\begin{array}{l}-0.0119^{\dagger} \\
(0.0051)\end{array}$ & $\begin{array}{l}-0.0013 \\
(0.0013)\end{array}$ \\
\hline$\%$ voting age pop union members & 3.40 & $\begin{array}{r}0.0237^{\dagger} \\
(0.0121)\end{array}$ & 0.0010 & $\begin{array}{c}0.0187 \\
(0.0117)\end{array}$ & 0.0008 & $\begin{array}{c}0.0143 \\
(0.0215)\end{array}$ & $\begin{array}{l}-0.0094 \\
(0.0059)\end{array}$ \\
\hline$\%$ voting age pop illiterate & 6.12 & $\begin{array}{l}-0.0432^{\dagger} \\
(0.0203)\end{array}$ & -0.0018 & $\begin{array}{l}-0.0392^{\dagger} \\
(0.0168)\end{array}$ & -0.0016 & $\begin{array}{l}-0.0236 \\
(0.0332)\end{array}$ & $\begin{array}{r}0.0196^{\dagger} \\
(0.0084)\end{array}$ \\
\hline$\%$ voting age pop foreign-born & 24.12 & $\begin{array}{c}0.0030 \\
(0.0063)\end{array}$ & 0.0001 & $\begin{array}{r}0.0215^{\ddagger} \\
(0.0052)\end{array}$ & 0.0009 & $\begin{array}{l}-0.0078 \\
(0.0101)\end{array}$ & $\begin{array}{l}-0.0108^{\ddagger} \\
(0.0026)\end{array}$ \\
\hline $\begin{array}{l}\text { value per voting age individual } \\
\text { crops }\end{array}$ & 484.54 & $\begin{array}{c}\cdot \\
-0.0002 \\
(0.0001)\end{array}$ & -0.0000 & . & & $\begin{array}{c}. \\
-0.0002 \\
(0.0001)\end{array}$ & \\
\hline manufacturing products & 0.65 & $\begin{array}{c}0.0120 \\
(0.0267)\end{array}$ & 0.0005 & . & & $\begin{array}{c}0.0120 \\
(0.0267)\end{array}$ & \\
\hline mineral products & 45.32 & $\begin{array}{c}0.0000 \\
(0.0005)\end{array}$ & 0.0000 & . & & $\begin{array}{c}0.0000 \\
(0.0005)\end{array}$ & \\
\hline railroad assessments & 215.81 & $\begin{array}{l}-0.0001 \\
(0.0001)\end{array}$ & -0.0000 & & & $\begin{array}{l}-0.0001 \\
(0.0001)\end{array}$ & . \\
\hline dummy $=1$ if county lumber producer & 0.17 & $\begin{array}{l}-0.1326 \\
(0.0871)\end{array}$ & -0.0055 & . & & $\begin{array}{l}-0.1326 \\
(0.0871)\end{array}$ & . \\
\hline dummy $=1$ if city of $25,000+$ & 0.12 & $\begin{array}{r}0.1701^{\dagger} \\
(0.0742)\end{array}$ & 0.0071 & . & & $\begin{array}{r}0.1701^{t} \\
(0.0742)\end{array}$ & \\
\hline no of hospital beds per capita & 0.01 & $\begin{array}{l}-1.7573 \\
(1.8047)\end{array}$ & -0.0732 & . & & $\begin{array}{l}-1.7573 \\
(1.8047)\end{array}$ & \\
\hline
\end{tabular}

Note. Standard errors are in parentheses. The symbols $\nmid$ and $\ddagger$ indicate that the coefficient is significantly different from 0 at least the 5 percent and 1 percent level, respectively. $\frac{\partial L}{\partial x}=\beta \frac{1}{n} \sum L(1-L)$, where $\beta$ is the vector of estimated coefficients, $L$ is the logistic distribution, and $\frac{\partial L}{\partial x}$ is in probability units.

Sources. See Table 3. 
equations, the coefficient on wealth becomes insignificant.

The regression results also show that interest groups were important. The fraction of doctors within a county was a significant, negative predictor of the probability of voting for the constitutional amendment and a significant, negative predictor of mean expected changes in utility when past voting was omitted from the regression. Voters in areas where there was a high proportion of doctors clearly did not approve of the amendment. The fraction of Christian Scientists becomes a significant predictor of both the probability of voting for the measure and expected changes in utilities only when voting variables are omitted from the regression, perhaps because of the strong negative correlation $(\rho=-0.52)$ between percent Christian Scientist and percent voting for Wilson. The fraction of voters who were union members was positively associated with the probability of voting for the constitutional amendment. When past voting behavior was omitted from the regression, the assocation was significant. However, the fraction of union members was not a significant predictor of differences in utility.

Voters for Wilson and Benson were more likely to vote for the amendment than voters for Hughes. The percentage voting for Wilson was a positive predictor of the mean difference in utilities, suggesting that Progressive voters approved of the health insurance amendment. When a southern dummy is added to the regressions, its coefficient is significantly negative and reduces the explanatory value of the voting variables because the south did not vote for Wilson. The percentage voting for Benson was a significant, negative predictor of voter abstention and thus a significant, positive predictor of the perception threshhold. The perception threshold was also significantly and positively related to literacy and negatively related to foreign birth.

Voter turnout for the election was only 59\%. In contrast, during the 1916 Presidential election, estimated voter turnout was $80 \%{ }^{28}$ Three weeks before the election, the Los Angeles

\footnotetext{
${ }^{28}$ The number of registered voters was obtained from California Secretary of State 1918 and 1916.
} 
Table 5: Determinants of Turnout Among Registered Voters in 1918 Election

\begin{tabular}{|c|c|c|c|c|c|c|c|}
\hline 58 obs & & \multicolumn{3}{|c|}{ adjusted $R^{2}=0.12$} & \multicolumn{3}{|c|}{ adjusted $R^{2}=0.16$} \\
\hline county level variables & mean & coef & std err & $\frac{\partial L}{\partial x}$ & coef & std err & $\frac{\partial L}{\partial \mu}$ \\
\hline intercept & & 1.6070 & 1.4609 & & 1.5501 & 1.2630 & \\
\hline value per voting age individual & & & & & & & \\
\hline logarithm of taxable wealth & 8.08 & -0.1807 & 0.1766 & -0.0427 & -0.1740 & 0.1635 & -0.0411 \\
\hline$\%$ voting age pop doctors & 0.21 & 0.1403 & 0.9648 & 0.0331 & 0.1803 & 0.8841 & 0.0426 \\
\hline$\%$ religous members Christian & & & & & & & \\
\hline Scientists $\times 100$ & 14.34 & -0.0019 & 0.0075 & -0.0005 & -0.0019 & 0.0036 & -0.0005 \\
\hline \% voting age pop union members & 3.40 & 0.0184 & 0.0155 & 0.0044 & 0.0192 & 0.0146 & 0.0045 \\
\hline$\%$ voting age pop illiterate & 6.12 & -0.0205 & 0.0283 & -0.0049 & -0.0209 & 0.0261 & -0.0049 \\
\hline \% voting age pop foreign-born & 24.12 & 0.0086 & 0.0091 & 0.0020 & 0.0080 & 0.0083 & 0.0019 \\
\hline \% votes cast for Wilson in 1916 & 49.73 & 0.0006 & 0.0138 & 0.0001 & & & \\
\hline$\%$ votes cast for Benson in 1916 & 5.22 & -0.0066 & 0.0326 & -0.0016 & & & \\
\hline $\begin{array}{l}\text { value per voting age individual } \\
\text { crops }\end{array}$ & 45854 & ( 000 * & & 0.0001 & $00004^{*}$ & ב0000 & O \\
\hline manufacturing products & 0.65 & -0.0046 & 0.0407 & -0.0106 & -0.0447 & 0.0397 & -0.0106 \\
\hline mineral products & 45.32 & -0.0002 & 0.0007 & -0.0001 & -0.0002 & 0.0007 & -0.0000 \\
\hline railroad assessments & 215.81 & 0.0001 & 0.0002 & 0.0000 & 0.0000 & 0.0002 & 0.0000 \\
\hline dummy $=1$ if county lumber producer & 0.17 & 0.1550 & 0.1523 & 0.0367 & 0.1484 & 0.1446 & 0.0351 \\
\hline dummy $=1$ if city of $25,000+$ & 0.12 & -0.0816 & 0.1351 & -0.0193 & -0.0761 & 0.1209 & -0.0180 \\
\hline no of hospitals beds per capita & 0.01 & -0.8807 & 3.1022 & -0.2083 & -0.7854 & 2.9019 & -0.1857 \\
\hline
\end{tabular}

Note. The symbols $*, \dagger$, and $\ddagger$ indicate that the coefficient is significantly different from 0 at at least the 10,5 , and 1 percent level, respectively. $\frac{\partial L}{\partial x}=\beta \frac{1}{n} \sum L(1-L)$, where $\beta$ is the vector of estimated coefficients, $L$ is the logistic distribution, and $\frac{\partial L}{\partial x}$ is in probability units. See Table 3 for sources.

Times noted the low voter interest in the election and attributed it to war conditions and "the lack of pep on the part of candidates" (Los Angeles Times October 13). The influenza epidemic scared voters away from the polls, despite health department and physician announcements that if everyone wore a mask there would be no danger of contracting influenza in the polling place (Oakland Tribune November 5).

Table 5 shows the county characteristics which predict the probability of voting, among those registered to vote, in the 1918 election. Only crop value was a significant predictor of turnout and it was significant at only the $10 \%$ level. The fraction of the registered voters showing up at the polls was higher in counties with higher proportions of doctors, union members, and 
Table 6: Determinants of Turnout Among Potential Voters in 1918 Election

\begin{tabular}{|c|c|c|c|c|c|c|c|}
\hline 58 obs & & \multicolumn{3}{|c|}{ adjusted $R^{2}=0.29$} & \multicolumn{3}{|c|}{ adjusted $R^{2}=0.26$} \\
\hline county level variables & mean & coef & std err & $\frac{\partial L}{\partial x}$ & coef & std err & $\frac{\partial L}{\partial r}$ \\
\hline $\begin{array}{l}\text { intercept } \\
\text { value per voting age individual }\end{array}$ & & 0.2378 & 1.3319 & & 1.0731 & 1.2075 & \\
\hline logarithm of taxable wealth & 8.08 & -0.1127 & 0.1654 & -0.0027 & -0.1397 & 0.1585 & -0.0338 \\
\hline $\begin{array}{l}\text { \% voting age pop doctors } \\
\% \text { religous members Christ }\end{array}$ & 0.21 & -0.6221 & 0.8849 & -0.1508 & -1.0637 & 0.8481 & -0.2574 \\
\hline $\begin{array}{l}\text { \% religous members } \\
\text { Scientists } \times 100\end{array}$ & 14.34 & -0.0016 & 0.0069 & -0.0004 & -0.0055 & 0.0035 & -0.0013 \\
\hline$\%$ voting ag & 3.40 & 0.01040 & 0.0143 & 0.0025 & 0.0057 & 0.0141 & 0.0014 \\
\hline \% voting a & 6.12 & -0.0089 & 0.0259 & -0.0022 & -0.0116 & 0.0249 & -0.0028 \\
\hline$\%$ voting a & 24.12 & -0.0010 & 0.0084 & -0.0002 & 0.0025 & 0.0080 & 0.0006 \\
\hline$\%$ votes cast for Wilson & 49.73 & 0.0039 & 0.0126 & 0.0009 & & & \\
\hline $\begin{array}{l}\% \text { votes cast for Benson in } 1916 \\
\text { value per voting age individual }\end{array}$ & 5.22 & $0.0585^{*}$ & 0.0301 & 0.0142 & & & \\
\hline crops & 458.54 & -0.0002 & 0.0002 & 0.0000 & 0.0001 & 0.0002 & 0.0000 \\
\hline manufacturing products & 0.65 & -0.0291 & 0.0391 & -0.0071 & -0.0301 & 0.0397 & -0.0073 \\
\hline mineral products & 45.32 & -0.0002 & 0.0007 & -0.0000 & -0.0001 & 0.0007 & -0.0000 \\
\hline railroad & 215.81 & -0.0000 & 0.0002 & -0.0000 & 0.0000 & 0.0002 & -0.0000 \\
\hline dummy $=1$ i & 0.17 & 0.0473 & 0.1358 & 0.0115 & 0.0848 & 0.1339 & 0.0205 \\
\hline dummy $=1$ & 0.12 & -0.1071 & 0.1201 & -0.0260 & -0.1129 & 0.1118 & -0.0273 \\
\hline no of hospitals beds per capita & 0.01 & 1.0040 & 2.7741 & 0.2434 & -0.1514 & 2.7110 & -0.0366 \\
\hline
\end{tabular}

Note. The symbols $*, \dagger$ and $\ddagger$ indicate that the coefficient is significantly different from 0 at at least the 10,5 , and 1 percent level, respectively. $\frac{\partial L}{\partial x}=\beta \frac{1}{n} \sum L(1-L)$, where $\beta$ is the vector of estimated coefficients, $L$ is the logistic distribution, and $\frac{\partial L}{\partial x}$ is in probability units. See Table 3 for sources.

Christian Scientists, suggesting that interest groups may have been able to get the vote out, but the effect was small and insignificant. None of the other variables had a large impact either. A higher turnout would not have changed the outcome of the election.

Voter apathy can take the form of not registering to vote as well. Only $42 \%$ of all native-born or naturalized foreign-born individuals age 21 or over went to the polls. This type of voter apathy may bias the estimated coefficients if the mean characteristics of counties are not the mean characteristics of voters. However, none of the variables are significant predictors of turnout, suggesting that turnout bias is not a problem (see Table 6). 


\section{Explaining the Defeat}

The quantitative assessment of voting on the 1918 California health insurance referendum presented in this paper suggests that the persuasiveness of interest groups such as doctors and to a lesser extent trade unions did matter. Political affiliation was another important factor. But, none of the variables could fully account for the defeat of health insurance. The defeat was simply too resounding. A standard devation change in any of the variables would not have affected the outcome. Although it was not possible to examine the impact of all interest groups, such as insurance companies, had these groups made doctors twice as effective, they still would not have affected the outcome. These results suggest that explanations that have focused solely on the campaigns of interest groups have been too narrow.

Other possible explanations for the defeat of the health insurance amendment might be the impact of WWI, the predominance of individualist and liberal values in the United States (Hartz 1955), and popular disgust with regulatory politics. The only way to test whether the preferences of the American electorate differed from those of the European would be to compare referenda data across countries. But, the European welfare state arose not from referenda but from the political machinations of powerful heads of state. Although WWI undoubtedly colored the rhetoric of health insurance opponents, it seems an implausible explanation for such a resounding defeat. Anti-German sentiment was already strong at the beginning of 1917 and was strengthened by the submarine sinkings of American ships in March of 1917, well before the April vote in the California legislature. The treaty of Versailles was not signed until June of 1919, after a health insurance plan passed the New York State Senate.

Popular disgust with regulatory politics may have played a role in the defeat of health insurance. Fraud and graft were often mentioned in the campaign against health insurance. Skocpol (1992) has argued that the failure of the Progressive agenda can be traced to dissatisfaction 
with the federal pension program run for the benefit of Union Army veterans. This hypothesis seems unlikely. The Union Army pension program was not mentioned in any of the debates. Insurance fraud and the European experience were (e.g. Hoffman 1917; Illinois Social Insurance Commission 1919). Furthermore, the supporters of the health insurance cited the program that served WWI soldiers and which grew out of the Union Army pension program (e.g. Ohio Health and Old Age Insurance Commission 1919).

The relative importance of anti-German hysteria, disgust with regulatory politics, and anti-tax sentiment in the defeat of state provided health insurance can be assessed from an examination of newspaper editorials and advertisements shortly before the election. The newspapers that I examined were the Sacramento Bee, the San Jose Mercury Herald, the Oakland Tribune, the San Francisco Bulletin, the San Francisco Chronicle, the San Francisco Examiner, and the Los Angeles Times. The Sacramento Bee urged a yes vote for the measure, on the grounds that it was purely an enabling amendment. The San Jose Mercury Herald, the San Francisco Bulletin, and the San Francisco Examiner printed no editorial recommendations regarding health insurance. ${ }^{29}$ The San Francisco Examiner printed side by side pro and con articles. The Oakland Tribune, the San Francisco Chronicle, and the Los Angeles Times were opposed. Although all three newspapers noted the German origin of health insurance, only the Los Angeles Times emphasized this feature, urging the defeat of health insurance as a patriotic duty and entitling an editorial "Swat the Huns on the Ballot" (Los Angeles Times, October 27, 1918). In contrast the San Francisco Chronicle entitled its voting recommendations "Guide Will Assist Voters to Defeat Tax Eater Hordes" (San Francisco Chronicle, November 5, 1918), emphasizing the cost of the program, that benefits would be given to a small class of people, and that a new commission with unlimited powers would be created. The Oakland Tribune primarily emphasized the cost of the program.

\footnotetext{
${ }^{29}$ The San Francisco Examiner considered prohibition the only issue of the campaign. It was in favor.
} 
Two advertisements in favor of health insurance were run. Both of them mentioned Senator Hiram Johnson's endorsement of the measure and both of them appealed to workers' familiarity with workmen's compensation by stating that health insurance "does for sickness what workmen's compensation does for industrial accidents. It includes the family." Ads opposing health insurance generally took the form of a complete list of ballot recommendations. These were paid for by the San Francisco Chamber of Commerce, the Civic League, the Legislative Committee of the San Francisco Real Estate Board, and the Governing Committee of the Los Angeles Realty Board. Only the Civic League recommendations gave any reason for voting against health insurance and that was "Creation of new commission with unlimited powers. Makes insurance compulsory; creates an unlimited tax."

The San Jose Mercury Herald ran advertisements opposing health insurance that specifically singled out the amendment. Ads appeared listing San Jose dentists, doctors, attorneys, and bankers who opposed the health amendment. An ad run November 5 and 6 pointed out the quality of care would suffer because "The care and attention of insurance physicians will be perfunctory and will lack that personal interest which is so necessary to the patient." The advertisement went to add,

“This Prussian device will raise California taxes $\$ 15,000,000$ in one year."

"It will require $\$ 50,000,000$ a year to run the Health Insurance business - you will pay it all."

On November 5 there was also an ad in the form of a long article entitled "Compulsory Insurance a Failure in England. No Improvement in Public Health. Medical and Pharmaceutical Professions Are Affected."

The advertisement campaign is summarized in Table 7. There were no advertisements against health insurance in either the Oakland Tribune or the Sacramento Bee. In the San Francisco Bulletin, the San Francisco Chronicle, the San Francisco Examiner, and the Los Angeles Times, 
Table 7: Advertisements Relating to Health Insurance Before 1918 Election

\begin{tabular}{l|r|rrr}
\hline & \multicolumn{5}{c}{ number of advertisements } \\
\hline & favoring & \multicolumn{4}{c}{ opposing } \\
\hline \multicolumn{1}{c}{ newspaper } & & \multicolumn{4}{c}{ ballot } & indiv- \\
Los Angeles Times & 1 & 1 & 1 & 0 \\
Oakland Tribune & 2 & 0 & 0 & 0 \\
Sacramento Bee & 1 & 0 & 0 & 0 \\
San Francisco Bulletin & 2 & 4 & 4 & 0 \\
San Francisco Chronicle & 2 & 3 & 3 & 0 \\
San Francisco Examiner & 2 & 8 & 8 & 0 \\
San Jose Mercury Herald & 1 & 4 & 0 & 4 \\
\hline
\end{tabular}

Note. The advertisements favoring health insurance appeared in the Los Angeles Times on November 4, in the Oakland Tribune November 2 and 3 , in the Sacremento Bee on November 2, in the San Francisco Bulletin on November 2 and 4, in the San Francisco Examiner and San Francisco Chronicle November 3 and 4, and in the San Jose Mercury Herald on November 5 . The advertisements that were complete ballot recommendations appeared in the Times on November 4 , in the Bulletin on November 2 and 4, and in the Chronicle and Examiner on November 2, 3 , and 4 . The advertisements in the Mercury Herald were run October 24 and November 4 and 5. 
the only advertisements against the health insurance took the form of complete lists of ballot recommendations. Only the San Jose Mercury Herald's opposing ads were specifically targetted towards the health insurance amendment. Thus, just before the election, the pro health insurance forces do not appear to have been outspent in the advertising campaign. ${ }^{30}$

The other information that voters received about health insurance just before the general election was in newpaper reports of a public hearing on health insurance organized by the California Social Insurance Committee on October 22 in San Francisco. The San Franscisco Examiner, the San Francisco Chronicle, and the San Francisco Bulletin reported on the public meeting, emphasizing the alien nature of health insurance, its cost, and its failure in Britain, respectively. On November 5 the San Jose Mercury News and the Los Angeles Times ran articles outlining the stand of Frederick Hoffman of Prudential Insurance which dwellt largely on the failure of state provided health insurance to improve public health.

What the editorials, advertisements, and articles suggest is that although there was anti-German hysteria, disgust with commission politics, and uncertainty over exactly what type of bill would result from a yes vote for the amendment, cost was the primary concern. A huge bureaucracy would need to be created and the cost to the State would be "nearly the entire present cost of the strictly government expenses of the State" (San Francisco Chronicle October 25). The need for such a large expenditure was unclear. The weak relationship between income and health insurance and income and medical care suggests that access to either health insurance or medical care does not appear to have been a problem. Both health insurance and medical care were of rather limited use. There was much evidence that state provided health insurance would not improve public health and that only those who currently had health insurance, a relatively small group, would actually benefit. Those who preferred self-insurance would be faced with a

\footnotetext{
${ }^{30}$ The outspending hypothesis has been advocated by Viseltear (1969). However, the anti-health insurance forces did have the benefit of newpaper editorials and may have already felt that they had public opinion on their side.
} 
large expense.

\section{Concluding Remarks}

This paper has used both qualitative and quantitative evidence to analyze the vote on the 1918 California health insurance referendum. The quantitative evidence showed that the persuasiveness of interest groups such as doctors and to a lesser extent trade unions did matter. Political affiliation mattered as well. However, none of the variables could explain such a resounding defeat. Therefore differences between the European and American health care systems cannot be explained by the relative strength of different interest groups. I then examined qualitative evidence from newspaper editorials, advertisements, and articles. These suggested that the measure was defeated primarily on cost grounds. My findings are in contrast to those of other researchers who have emphasized the role of a politically powerful medical profession and of World War I.

The defeat of the health insurance measure on cost grounds suggests that even before World War II voters may have behaved as "fiscal conservatives" (Peltzman 1992). The greater centralization of power in Europe and the absence of referenda may explain why state-provided health insurance was passed in these countries. Using recent data, Matsusaka (1995) finds that state spending is higher in states that do not use iniatives and concludes that the iniative leads to a reduction in the overall size of government and limits the level of distributional activities. Fishback and Kantor (1994) argue that complex laws like workers' compensation often faced opposition in referenda because of the magnitude of the proposed changes and the dearth of information with which voters could form expectations. They find that the more extreme components of workers' compensation laws, such as generous benefits, state insurance, or an expanded bureacracy, had to be weakened or eliminated in order to win voters' support. State-provided health insurance would have resulted in a far vaster bureaucracy and have cost much more than any proposed workers' 
compensation program and would have been even more of a "plunge in the dark" for voters."

Why weren't state provided health insurance plans modified until a plan could win voter support? After World War II this is indeed what happened with the provision of health insurance to the poor and the old. But, the primary aim of private health insurance in 1918 was to provide cash benefits to employed, prime-aged males. All that state-provided health insurance would have done would have been to change the financing of the system, not its actual structure. Coverage would have been limited, as noted in editorials opposing health insurance. Had benefits been restricted, coverage through the private sector would have been even more attractive than the proposed coverage through the government sector and voter support for state-provided health insurance perhaps even smaller.

\section{References}

[1] American Medical Association. 1918. American Medical Directory, 1918. Chicago: American Medical Association.

[2] Anderson, Olin. 1951. "Compulsory Medical Care Insurance, 1910-1950." In T. Sellin and J.C. Charlesworth, Eds., Medical Care for Americans. In The Annals of the American Academy of Political and Social Science. 273 (January): 106-113.

[3] California Blue Book or State Roster, 1911. Sacramento, CA: California State Printing Office. 1913.

[4] California Bureau of Labor Statistics. 1892. "A Survey of 3,493 Wage-Earners in California, 1892." Fifth Biennial Report of the California Bureau of Labor Statistics. Historical Labor Statistics Project, Institute of Business and Economic Research, University of California, Berkeley, CA, 94720.

[5] California Bureau of Labor Statistics. 1918. Eighteenth Biennial Report of the Bureau of Labor Statistics of the State of California, 1917-1918. Sacramento, CA: California State Printing Office.

\footnotetext{
${ }^{31}$ A "plunge in the dark" is how Florence Kelly, General Secretary of the Consumers" League and official representative of women wage earners, described compulsory insurance (cited in Hoffman 1917).
} 
[6] California Registrar of Voters. 1918. Statement of Vote. Sacramento, CA: California State Printing Office.

[7] California Social Insurance Commission. 1917. Report of the Social Insurance Commission of the State of California. Sacramento, CA: California State Printing Office.

[8] California State Board of Equalization. 1918. Report of the California State Board of Equalization for 1917-1918. Sacramento, CA: California State Printing Office.

[9] California State Tax Commission. 1917. Report of the State Tax Commission of the State of California. Sacramento, CA: California State Printing Office.

[10] Clubb, Jerome M., William H. Flanigan, and Nancy H. Zingale. Electoral Data for Counties in the United States: Presidential and Congressional Races, 1840-1972, ICPSR 8611. Ann Arbor, MI: Inter-university Consortium for Political and Social Research.

[11] Dewhurst, J. Frederic, and Associates. 1955. America's Needs and Resources. New York: The Twentieth Century Fund.

[12] Emery, John Charles Herbert. 1993. The Rise and Fall of Fraternal Methods of Social Insurance: A Case Study of the Independent Order of Oddfellows of British Columbia Sickness Insurance, 1874-1951 (British Columbia). Unpublished Phd. Dissertation. University of British Columbia.

[13] Fishback, Price and Shawn Kantor. 1994. "Coalition Formation and the Adoption of Workers' Compensation: The Case of Missouri, 1911 to 1926." In C. Goldin and G. Libecap, Eds. The Regulated Economy. Chicago: The University of Chicago Press: 259-298.

[14] Hartz, Louis. 1955. The Liberal Tradition in America. New York: Harcourt Brace.

[15] Hoffman, Frederick L. 1917. Facts and Fallacies of Compulsory Health Insurance. Newark, NJ: Prudential Press.

[16] ICPSR (Inter-University Consortium for Political and Social Research). Historical Demographic, Economic and Social Data: The United States, 1790-1970, ICPSR 3. Ann Arbor, MI: Inter-university Consortium for Political and Social Research.

[17] Illinois Social Insurance Commission. 1919. Report of the Health Insurance Commission of the State of Illinois. Springfield, IL: Illinois State Journal Co., State Printers.

[18] Kalt, J.P. and M.A. Zuppan. 1990. "The apparent ideological behavior of legislators: Testing for principal-agent slack in political institutions." Journal of Law and Economics. 33: 103131.

[19] Matsusaka, John G. 1992. "Economics of Direct Legislation." Quarterly Journal of Economics. 107(2,May): 541-572. 
[20] Matsusaka, John G. 1995. "Fiscal Effects of the Voter Initiative: Evidence from the Last 30 Years." Journal of Political Economy. 103: 587-623.

[21] Naylor, C.D. 1986. Private Practice, Public Payment: Canadian Medicine and the Politics of Health Insurance, 1911-1966. Kingston, Canada: McGill-Queen's University Press.

[22] Ohio Health and Old Age Insurance Commission. 1919. Health, Health Insurance, Old Age Pensions. Columbus, OH: F.J. Heer Printing Co.

[23] Peltzman, Sam. 1984. "Constituent Interest and Congressional Voting." Journal of Law and Economics. 27(1,April): 181-210.

[24] Peltzman, Sam. 1992. "Voters as Fiscal Conservatives." Quarterly Journal of Economics. 107(2): 327-362.

[25] Poole, Keith T. and Howard Rosenthal. 1993. "The Enduring Nineteenth-Century Battle for Economic Regulation: The Interstate Commerce Act Revisited." Journal of Law and Economics. 36(2,October): 837-860.

[26] Rogin, Michael Paul and John L. Shover. Political Change in California. Westport, CT: Greenwood Publishing Corporation.

[27] Romer, Thomas and Howard Rosenthal. 1979. "Bureaucrats versus Voters: On the Political Economy of Resource Allocation by Direct Democracy." Quarterly Journal of Economics. 93(November): 563-587.

[28] Rosen, G. 1977. "Contract or Lodge Practice and its Influence on Medical Attitudes to Health Insurance." American Journal of Public Health. 67: 274-378.

[29] Rubinow, Isaac. 1916. Standards of Health Insurance. New York: H. Holt and Company.

[30] Shonick, William. 1995. Government and Health Services. Oxford: Oxford University Press.

[31] Skocpol, Theda. 1992. Protecting Soldiers and Mothers: The Political Origin of Social Policy in the United States. Cambridge, MA: Harvard University Press.

[32] Starr, Paul. 1982. The Social Transformation of American Medicine. Basic Books.

[33] United States Bureau of the Census. 1906. Census of Religious Bodies. Washington, DC: Government Printing Office.

[34] United States Bureau of the Census. 1926. Census of Religious Bodies. Washington, DC: Government Printing Office.

[35] United States Department of Labor. Bureau of Labor Statistics. Cost of Living in the United States, 1917-1918. ICPSR 8299. Ann Arbor, MI: Inter-university Consortium for Political and Social Research. 
[36] Viseltear, Arthur J. 1969. "Compulsory Health Insurance in California, 1915-1918." Journal of the History of Medicine and Allied Sciences. 24(April): 151-182.

[37] Warren, B.S. and Edgar Sydenstricker. 1916. "Health Insurance: Its Relation to the Public Health." Public Health Bulletin No. 76 (March) , United States Public Health Service.

[38] Whaples, Robert and David Buffum. 1991. "Fraternalism, Paternalism, the Family, and the Market: Insurance a Century Ago." Social Science History. 15(1): 97-122. 